\title{
The new media and the evolution of the human psyche
}

\author{
Elena E. Pronina \\ Faculty of Journalism, Lomonosov Moscow State University, Moscow, Russia \\ Corresponding author: E-mail: pronina.elena@gmail.com
}

Background. The emergence of the new media - the Internet and social networks has had a considerable impact not only on media technologies, genres of journalism, and environment the journalist works in, but also on every user of global communication. Ongoing changes are extending their influence to all the media, making it important for researchers to reconsider the role of journalism in modern society and the perspectives of its development in the information age.

Objective. In order to get an adequate picture of the ongoing changes, we need to understand how the new media impact their users. We studied the dependence of people's self-identification (values) on their Internet activity and use of social networks. Our hypothesis was that use of the new media leads to the formation of a new personality type, among whose most distinct characteristics is a much stronger desire for selfdetermination.

Design. The characteristic features of respondents' self-identification were studied by their choosing a reference group. Their desire for self-determination was revealed by giving them ethical dilemmas. A questionnaire was devised to study their communicative preferences and attitudes. Various methods of mathematical analysis were applied.

Results. Factor analysis revealed two psychological types of people, different from others in how much they use the new media. Statistical analyses of the group comparison data showed that the desire for self-determination is considerably higher for active users, and is especially high for those who adhere to spiritual values (by the Maslow pyramid). A two-way ANOVA confirmed the overall effect of these two factors - spiritual values and the new media - on the desire for self-determination.

Conclusion. The data obtained show that the new media support people's desire for self-determination. Using the new media and thereby acquiring the identify of a journalist becomes an important factor of personality development and is in line with the general evolution of the psyche.

Keywords: identity of a communicator, media psychology, citizen journalism, self-determination, new media 


\section{Introduction}

The development of the Internet and the new media is having a considerable impact on the media worldwide and places the future of journalism at the top of the agenda (Young \& Carson, 2016; Deuze, 2008; Vartanova, 2015; Prognozy, 2017; Lazutina, 2013). According to media experts, "the spread of media information through social networks and new channels has a considerable effect on the work of journalists and the understanding of the target audience" (Mediamakers, 2016, p. 19). We see changes not only in technologies and genres (Kokhanov, Kravtsov, \& Shkondin, 2015; Frolova, 2014), journalists' working environments (Vyrkovskiy et al., 2016), and social frames (Vartanova, 2014), but also in man himself (Kuznetsova, 2011; Kuznetsova \& Chudova, 2008; Chudova, N.V., Evlampieva, M.A., \& Rakhimova, N.A., 2002).

Today the new communication formats provide everyone with a means of creating and transmitting messages and even make it possible for individuals to have permanent media channels of their own (Amzin et al., 2016). This has changed the situation radically: the "big" media are in decline, while the "individual" ones are winning large audiences (Mediamakers, 2016). Blogs and social networks are overtaking well-known publications in popularity and are successfully competing with traditional sources of information. We live in a situation no one could ever have imagined: The "big" media are losing in their competition with the Internet and social networks in "the holy of holies" - the creation of news content - and the audience "looks on the institutional media as an information filter or means of verification, rather than a source of information" (Loseva, 2016, p. 53). The circulation of newspapers and magazines is declining, while popular blogs can sometimes have an audience of several million. Does this mean that journalism as such is disappearing, and that professional journalists are becoming an endangered species?

Before the Internet came into being, when institutional media entirely dominated the information space and the audience did not have its own voice, it was the personal qualities of a journalist that were very often the only guarantee of the reliability of information and gave the last hope for the protection of an ordinary person. Now the mass media have turned into a tool for information warfare, with journalists acting like technical personnel serving a propaganda machine. As a result, problems of professional ethics and professional identity have become a burning issue (Verbitskaya, 2006). However, electronic technologies have also made it possible for the "audience" to access information space and publish their own content there or to search for information they need directly. How does all this affect professional journalism, or the average person?

For a number of years, the Center of Media Psychology at the Moscow University Faculty of Journalism has been doing research on the identity of the journalist (and communicator in general) in the era of global mass communication. More than a thousand respondents participated in the research.

As was stated in our previous publications, active Internet users are significantly different from people preferring the traditional media, in terms of striving for the truth and the desire for self-determination (Pronin \& Pronina, 2013). Moreover, active participation in social networks is accompanied by less stereotyped thinking and less interest in tabloids and glossy magazines (Pronina, 2014). And finally, it is rather symptomatic that the desire for self-determination and getting 
full information correlates positively with using the Internet and social networks, and negatively with watching TV (the index of differences on the Mann-Whitney U test was quite high, with the probability of error 0.003 ). Hence we can speak about two different types of influence exerted by the traditional and the new media.

The next stage of the research gave us an even better picture of how the new mass media affect the audience. Another 400 respondents took part, including student journalists, professional journalists, and people who do not work in the mass media. Their ages were $20-50$ years.

The research objective was to study the influence of the new media on the communicator. It involved analysis of the respondents' self-identification, depending upon how active they were as Internet and social network users.

Our hypothesis was that the new media - the Internet and social networks contribute to the formation of a new personality type, whose most distinctive characteristic is a much stronger desire for self-determination.

\section{Methods}

The respondents were asked to complete a questionnaire which consisted of two parts:

1. The "Communication Preferences Form", with questions relating to information preferences and habits, attitude to modern journalism and the blogosphere, intensity of using the Internet and social networks, and assessment of the prospects for the development of journalism;

2. "The Dilemmas" form, with ten pairs of alternative statements dealing with the most urgent and controversial issues of modern mass communication.

Both of these methods, which had the goal of studying different aspects of the identity of the communicator, had been worked out by a group of researchers under the guidance of E. I. Pronin (2002).

The "Communication Preferences Form" was intended to collect data on the respondents' habits and character traits on the basis of their self-description. It was designed to reveal the dominant values of a respondent based on the reference group they chose. The following question was asked: "Which social circle would you like to belong to?" The options to answer this question were the nine groups that had been established earlier when the preferences of the audience were analyzed.

The description of each group was made in correspondence with A. Maslow's hierarchy of motives and needs (Maslow, 1987), VALS (Values and Lifestyles) models of the stratification of the audience (Mitchell, 1984), and by using the results of the factor analysis of the surveys conducted earlier (Pronin \& Pronina, 1995). Each group had its own number (unknown to the respondents), which reflected a particular motive in Maslow's hierarchy of motives and needs, from the basic motives to the meta-motives (self-actualization) - nine groups altogether. The basic motives included acceptance and recognition; the meta-motives - knowledge, justice, self-actualization, overcoming, creativity, altruism, independence. The respondents could choose a reference group from the nine suggested options, or if none of them seemed suitable, they could mark the desirable social circle as "other". 
Table 1. The options to answer the question "Which social circle would you like $\mathrm{t}$ o belong to?"

\begin{tabular}{|c|c|c|}
\hline $\begin{array}{l}\text { Number } \\
\text { of group }\end{array}$ & Brief description & $\begin{array}{c}\text { Dominant need } \\
\text { (not shown to respondents) }\end{array}$ \\
\hline 1 & $\begin{array}{l}\text { Have lots of relationships, like club life, } \\
\text { parties, public events. Their main quality is } \\
\text { sociability. }\end{array}$ & Emotional attachment, acceptance \\
\hline 2 & $\begin{array}{l}\text { Make useful contacts. Have a way with } \\
\text { people. Career-oriented. Their main quality } \\
\text { is ambition. Like to be seen and listened to. }\end{array}$ & Social status, recognition \\
\hline 3 & $\begin{array}{l}\text { Have a desire for knowledge. Knowledgeable } \\
\text { in one or several subjects. Their main quality } \\
\text { is erudition. Behave as if they were planning } \\
\text { to study at a university again. }\end{array}$ & Knowledge \\
\hline 4 & $\begin{array}{l}\text { Protesters. Fighters for justice. Seekers for } \\
\text { the truth. Their main quality is critical think- } \\
\text { ing. Love to argue. }\end{array}$ & Justice \\
\hline 5 & $\begin{array}{l}\text { Treat everything in a non-standard way. Are } \\
\text { always looking for something unusual. Their } \\
\text { main quality is originality. Present things in } \\
\text { an unusual way. Have a vivid imagination. }\end{array}$ & Self-expression \\
\hline 6 & $\begin{array}{l}\text { See any difficult situation as a challenge. } \\
\text { Ready to take a risk. Their main quality is } \\
\text { adventurism. Eager to be the first. }\end{array}$ & Overcoming \\
\hline 7 & $\begin{array}{l}\text { Do not worry about tomorrow. Things take } \\
\text { care of themselves in their lives. Tend to } \\
\text { selflessly support other people. Their main } \\
\text { quality is being carefree. They tend to come } \\
\text { to the help of others because of their charac- } \\
\text { ter traits. }\end{array}$ & Altruism \\
\hline 8 & $\begin{array}{l}\text { Devote a lot of time to the arts. Genuinely } \\
\text { interested in theatre, cinema, literature, new } \\
\text { types of art. Welcome any expression of } \\
\text { creativity, which is their main quality. Able to } \\
\text { perceive the spirit of the times. }\end{array}$ & Creativity \\
\hline 9 & $\begin{array}{l}\text { Always choose what they are interested in. } \\
\text { As a rule, they work in jobs they like. Their } \\
\text { main quality is correctness. They pursue } \\
\text { their own interests, but not at the expense of } \\
\text { others. }\end{array}$ & Independence \\
\hline 0 & Other & \\
\hline
\end{tabular}

The descriptions of the groups were not exhaustive and mono-semantic, as their purpose was not to classify the respondents but to stimulate their self-disclosure. A brief and incomplete description leaves room for the imagination and allows a respondent to be more flexible in applying it to himself. This technique, which is used in projective psychological methodologies, stimulates the respondents to open up in the desired way. 
The rest of the points on the questionnaire were intended to flesh out the initial self-identification by revealing the behavioural attitudes and information preferences of the respondents, including their participation in network communication, preferred information channels, understanding of professional journalistic ethics, etc.

The second questionnaire - "The Dilemmas" - was intended to measure the strength of the desire for self-determination and truth. Self-determination in this particular case was understood as the wish of an individual to make choices in different situations by themselves, independently, and to be able to work out what to do on the basis of all information available. Each of the dilemmas dealt with an important ethical antinomy typical of modern information society, such as information openness and accessibility, public safety, journalistic ethics and political correctness, the priority of private or public interests. This methodology was described earlier (Pronina, 2014).

\section{Research Procedure and Data Processing}

The poll was conducted by handing out questionnaires, and online with the Simpoll service.

The statistical package IBM SPSS 20 was used to process the data, as well as frequency analysis, correlation analysis, factor analysis, and parametric and nonparametric criteria for the comparison of groups.

\section{Results}

\section{Analysis of the Values of the Respondents}

The frequency analysis of the answers to the question about the preferred social circle revealed the following distribution of dominant motives (\%):

In Figure 1, we see that the motive of independence (Group 9) and that of recognition (Group 2) are in the first and second place. It should be noted that

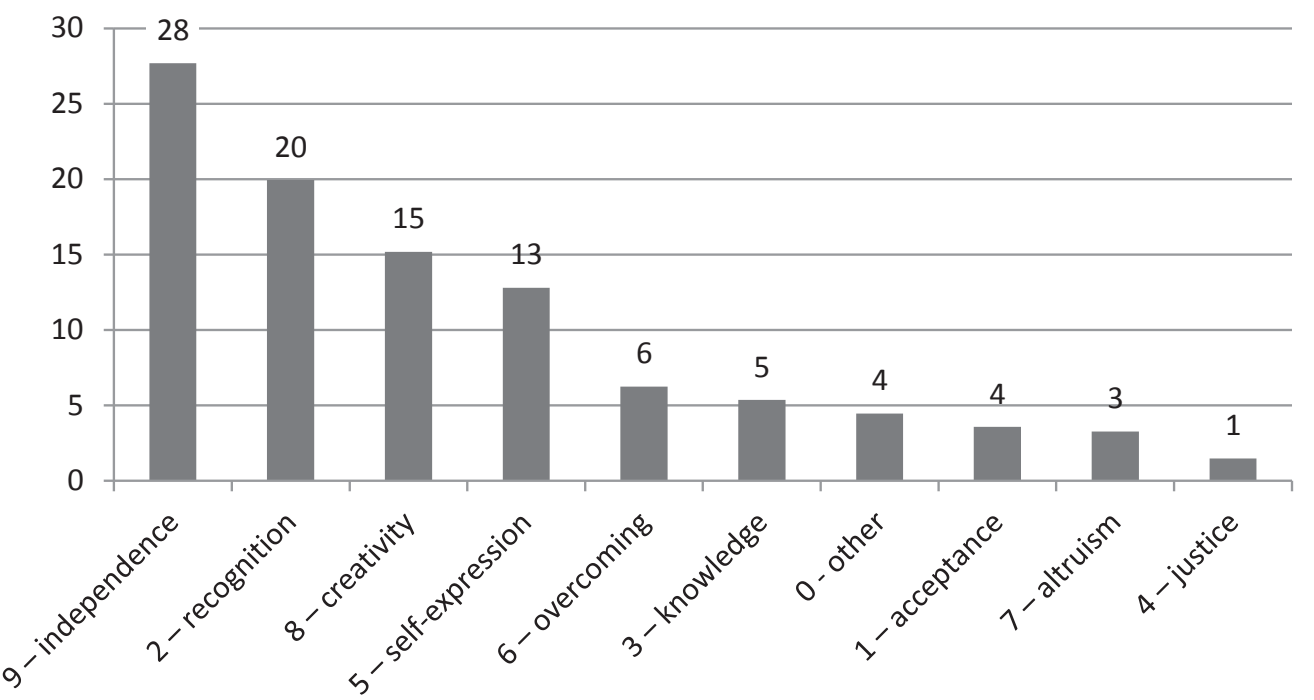

Figure 1. Frequency distribution of the dominant motives (\%) 
the need for independence corresponds with Maslow's top existential needs, while the need for recognition is connected with motivation for achievement, i.e., one of the basic needs. The difference in popularity between the groups is not large; however, the option of independence is chosen slightly more often, which means that the meta-level motivation still prevails. There is reason to believe that it is no coincidence that these groups are the leaders: The two dominant groups represent two major ways of self-identification and two basic types of identity. This assumption can be checked by comparing the subjective self-identification data with the objective picture of oneself. The latter can be reconstructed from the answers of the respondents to those questions that deal with information preferences, habits, and life attitudes.

\section{Typology of the Communicative Behaviour of Respondents}

A factor analysis was conducted in order to analyze the structure of a sample group in terms of communication preferences and life attitudes. The respondents themselves were used as the objects that were to be grouped, and the grounds for grouping them were similarities in how they answered the questionnaire. Calculations were done with the help of the Varimax rotation program (statistic package IBM SPSS Statistics 20), and two factors characterizing two basic types of answers were identified. Depending on the type of answers, the respondents were divided into two groups, each with its own communication pattern.

The comparison of the groups by different criteria, such as Student's t-distribution, the Mann-Whitney U test, and an analysis of variance (ANOVA), showed that the difference between the two types of respondents was primarily in how they used new means of communication. It turned out that the first group spent less time on social networks than the second group. And this difference was statistically very significant. Furthermore, the second group used the new social media, like Instagram and Twitter, a lot more often. They also had more subscribers to their network accounts, and tended to turn to social networks and blogs when searching for information. Therefore the first type of people were described as "moderate users" (of the new media), and the second type, devoted users of new communication formats, got the name of "active users" (of the new media). Among such respondents there were none who didn't use the new media at all. So there are just two gradations: moderate and high. However, the difference between them turned out to be not only quantitative, but also had to do with the attitude of the respondents toward information and even life itself.

For example, "moderate users" tended to choose to work for reputable "stateowned media, or local newspapers that could offer career opportunities", while "active users" preferred "large information agencies, such as Itar TASS, RIA Novosti, or Interfax".

There were also differences in interpersonal communication ethics. Supporters of a "moderate" communication style were more intolerant of their subscribers using obscene language. Network communication "fans" react negatively to "reposts containing doubtful messages about people who need help". They also had different attitudes to self-advertisement in one's own blog: Network communica- 
tion supporters were more tolerant of that, while the "moderate" users regarded such behavior as "emotional pressure", "imposing one's opinion on others". All the above-mentioned differences are statistically significant according to the multiple comparison tests conducted in the framework of the ANOVA and using the criteria of Student's t-distribution and the Mann-Whitney U test.

The analysis allows us to draw the conclusion that the communicative types identified reflect not only information preferences, but also the morals and ethics of the users - i.e., there are good grounds to consider them personality types. The ratio between communicative types 1 and 2 expressed as a percentage is $57 \%$ to $47 \%$. The number of respondents with the traditional communication pattern is a little higher.

\section{Correlation Between Value-Based Self-Identification and Communicative Types of Behavior}

Further research showed that the communicative types described above statistically correlate to a high degree with the dominant needs (linear correlation coefficient $\mathrm{p}$ $<0.01)$. In other words, there is a connection between the objective stratification of the sample (on the basis of factor analysis of their answers) and the subjective selfidentification of the respondents (judging by the reference group they chose). According to Table 2 , the respondents of the first type (moderate users) are more likely to be found in groups 3-9, which correspond to various forms of self-actualization; those of the second group are more likely to be in groups 1 and 2, which focus more on basic needs, or in the group where people were unable to make a choice.

Table 2. Ratio of dominant motives in psychotypes (\% of respondents)

\begin{tabular}{cccccccccccc}
\hline & \multicolumn{10}{c}{ Dominant motives } \\
\cline { 2 - 9 } $\begin{array}{c}\text { Com- } \\
\text { mun- }\end{array}$ & $\mathbf{0}$ & $\mathbf{1}$ & $\mathbf{2}$ & $\mathbf{3}$ & $\mathbf{4}$ & $\mathbf{5}$ & $\mathbf{6}$ & $\mathbf{7}$ & $\mathbf{8}$ & $\mathbf{9}$ \\
$\begin{array}{c}\text { icative } \\
\text { types }\end{array}$ & other & $\begin{array}{c}\text { accep- } \\
\text { tance }\end{array}$ & $\begin{array}{c}\text { recog- } \\
\text { nition }\end{array}$ & $\begin{array}{c}\text { know- } \\
\text { ledge }\end{array}$ & $\begin{array}{c}\text { jus- } \\
\text { tice }\end{array}$ & $\begin{array}{c}\text { self- } \\
\text { expres- } \\
\text { sion }\end{array}$ & $\begin{array}{c}\text { over- } \\
\text { com- } \\
\text { ing }\end{array}$ & $\begin{array}{c}\text { altru- } \\
\text { ism }\end{array}$ & $\begin{array}{c}\text { creati- } \\
\text { vity }\end{array}$ & $\begin{array}{c}\text { inde- } \\
\text { pen- } \\
\text { dence }\end{array}$ & Total \\
\hline type 1 & 4 & 3 & 13 & 7 & 2 & 14 & 6 & 4 & 18 & 31 & 100 \\
type 2 & 5 & 5 & 29 & 3 & 1 & 11 & 7 & 3 & 12 & 24 & 100 \\
\hline
\end{tabular}

Note: Type $1=$ moderate users of new media. Type 2 = active users of new media.

Since every need (marked as the code of the group) has its number, which corresponds to its level within the pyramid of values, the result was a linear correlation.

If we take a look at how the communicative types correspond to the levels of the values in Maslow's pyramid (Table 3), we see that the correlation coefficients turn out to be even more significant, the probability of error being $<=0.001$ (Table 4). Group 1 (needing acceptance) relates to the third level within the pyramid, Group 2 to the fourth one (needing recognition), and Groups 3-9 to different layers within the fifth level. 
Table 3. Cross-tabulation of the communicative types and the levels of the values in Maslow's pyramid

\begin{tabular}{ccccc}
\hline & & \multicolumn{2}{c}{ Types } & \multirow{2}{*}{ Total } \\
\cline { 3 - 4 } & & “moderate" & “active" & \\
\hline \multirow{3}{*}{ Level in Maslow's pyramid } & 3 & 5 & 7 & 12 \\
& 4 & 26 & 41 & 67 \\
\hline Total & 5 & 154 & 88 & 242 \\
\hline
\end{tabular}

Table 4. Correlation between the communicative types and the values in Maslow's pyramid

\begin{tabular}{lcccc}
\hline & Value & $\begin{array}{c}\text { Asymptotic standard } \\
\text { error }\end{array}$ & Approx. T & Sig. \\
\hline $\begin{array}{l}\text { Chi-square }\left(\chi^{2}\right) \\
\begin{array}{l}\text { Pearson's correlation coef- } \\
\text { ficient }\end{array}\end{array}$ & 0.208 & & & 0.001 \\
$\begin{array}{l}\text { Spearman's correlation } \\
\text { coefficient }\end{array}$ & -0.197 & 0.056 & -3.583 & 0.000 \\
\hline
\end{tabular}

So, the first communicative type (moderate users) is statistically more likely to be on the fifth level of Maslow's pyramid, while the second one (active users) is more likely to be on the third or fourth. Moreover, we have confirmed the assumption expressed earlier, that the two leading groups of self-identification - Group 9 (independence) and Group 2 (recognition), in which most of the members belong to different types - represent two different patterns of behavior, and possibly two different types of identity.

Paradoxical as it may seem, there are proportionally more active users of the new media and network communication among the groups of the third and fourth level (needing acceptance and needing recognition) than among those of the fifth level (needing independence, etc.) - a fact that gives cause for thought. It may mean that the new and the traditional values are competing, and that the advocates of "eternal" values look down on the new technologies, while technologically advanced people try to reconsider the former priorities. However, the results of the research suggest that it is a combination of the two - holding onto one's values in life and involvement in modern mass communication formats - that has the best effect in people's development and strengthens their desire for selfdetermination.

To check this assumption, we did an analysis based on the two-way ANOVA methodology, in which values and Internet activity were considered to be the independent factors likely determining development. As is shown in Table 2, in each reference group there are representatives of both the "moderate" and the "active" type with regard to their attitude toward the new media. If the assumption is true about the combined influence of the two evolutionary factors (the value-based fac- 


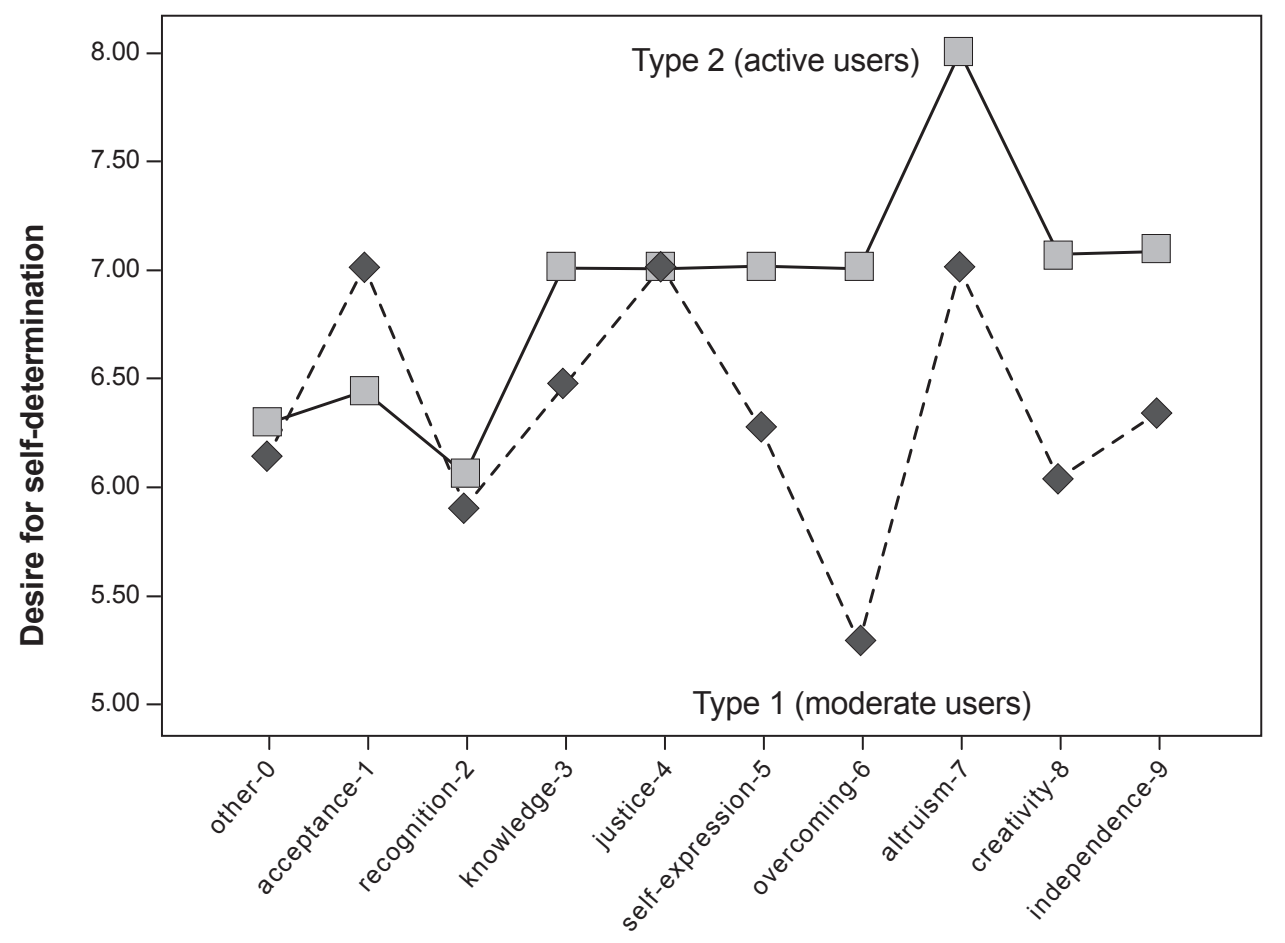

Figure 2. Average indexes of self-determination for members of different reference groups, depending on how actively they use the new media

tor and the technological one), then the indexes of self-determination will be considerably higher for those respondents who combine a spiritual orientation and active interest in the new media. Figure 2 shows indexes of self-determination for representatives of the reference groups described as "moderate" and "active".

As is seen in the diagram, the indexes of "active users" in each group (solid line) are, as a rule, higher than those of "moderate users" (dotted line). If we compare the "active users" with one another, it turns out that the active users of groups 3-9 have a higher level of desire for self-determination than the active users of groups 0-2. And the highest values are observed in the subgroup of "active altruists" (Group 7 - solid line). These facts support the above-mentioned assumption that spiritual values (especially altruistic ones) produce the best positive effect on a person when they are combined with new technologies.

Analysis of how values and digital competence correlate with self-determination produced even more impressive results.

Figure 3 compares two gradations of values: "basic values" and "spiritual values". The basic values cover all the levels below the fifth one in Maslow's pyramid. Groups 1 and 2, in which the values of the third level (emotional intimacy, emotional acceptance) and the fourth level (success, career, social status) dominate, fall into this category. The respondents who could not make a choice and specified "other" in their answers were also included in this category. Groups 3-9, with their focus on different types of self-actualization and on such values as knowledge, justice, self-expression, overcoming, creativity, altruism, and independence, fall into the category of spiritual values. 
Table 5. Effects of intergroup factors (two-way ANOVA)

\begin{tabular}{lccccc}
\hline \multicolumn{1}{c}{ Source } & $\begin{array}{c}\text { Sum of squares } \\
\text { type III }\end{array}$ & df & Mean square & F & Sig. \\
\hline Corrected model & $54.634 \mathrm{a}$ & 3 & 18.211 & 7.509 & $0^{* *}$ \\
Intercept & $10,560.828$ & 1 & $10,560.828$ & 4354.459 & $0^{* *}$ \\
$\begin{array}{l}\text { Factor_A (Types of media } \\
\text { activity) }\end{array}$ & 13.544 & 1 & 13.544 & 5.584 & $0.019^{*}$ \\
$\begin{array}{l}\text { Factor_B (Value levels) } \\
\text { Factor_A x Factor_B (“Types of }\end{array}$ & 20.119 & 1 & 20.119 & 8.296 & $0.004^{* *}$ \\
media activity” x “Value levels”) & 10.724 & 1 & 10.724 & 4.422 & $0.036^{\star}$ \\
$\begin{array}{l}\text { Error } \\
\text { Total }\end{array}$ & 805.197 & 332 & 2.425 & & \\
Corrected total & 14,707 & 336 & & & \\
\hline
\end{tabular}

Note. ${ }^{*}=$ correlation is significant at the 0.05 level; ${ }^{* *}=$ correlation is significant at the 0.01 level.

Figure 3 shows that the desire for self-determination is generally higher for respondents who have spiritual values, but is especially high for those of them who are active Internet and social network users. Calculations based on the twoway ANOVA confirmed the overall effect of the two independent factors - values and digital competence - on the need for self-determination. Table 5 makes it clear that not only does each of the factors have its own effect (the effect of digital competence was confirmed at $\mathrm{p}=0.019$, and that of values at $\mathrm{p}=0.004)$, but more importantly, their effect increases multifold when the factors are combined (the

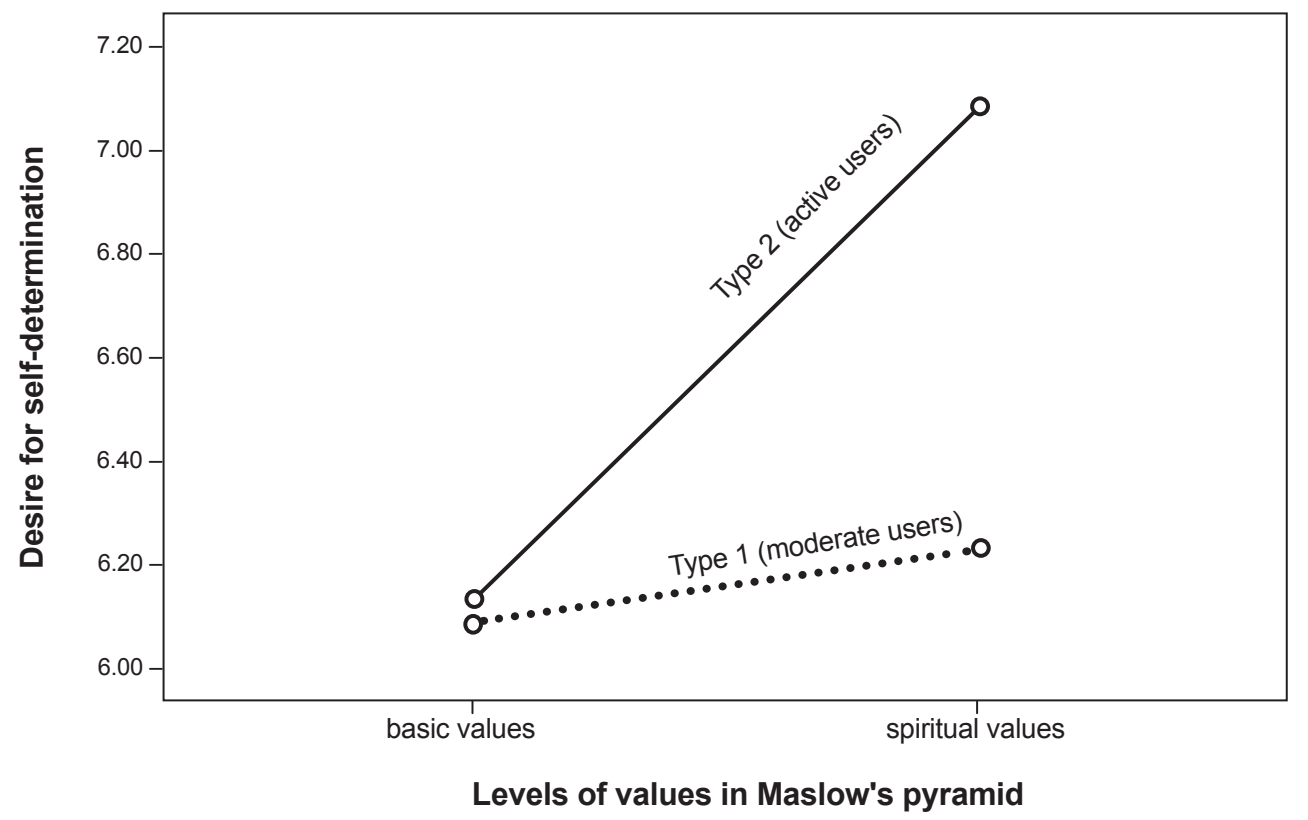

Figure 3. Average indexes of self-determination depending on value orientation and active use of the new media 
significance of mutual reinforcement was at $\mathrm{p}=0.036$ ). This supports the assumption made earlier that it is the combination of a value-based attitude towards life and involvement in modern formats of mass communication that has most contributed to the development of a psychotype with a strong desire for self-determination.

\section{Discussion}

To sum up, the original hypothesis has been proven: that active users of the new media have a stronger desire for self-determination and truth than others. This means that modern electronic media support and increase the desire for self-determination and truth, which is in line with the general vector of the evolution of the psyche. The highest level of self-determination occurs when altruistic values and network communication activity are combined.

The combination of selfless, prosocial motivation and communicative orientation is, in fact, an essential part of the professional identity of a journalist in its pure, "genotypic" form (Pronin, 2002). Changes occur in the work technologies used, professional requirements, and the format and style of texts. What remains unchanged is the identity of a journalist, which is determined by the essential social need for reliable information, on the one hand, and a person's desire for independence and the common good, on the other. In this regard, "citizen journalism", which is an essential part of an information society, serves as the most important means in the evolution of a person.

By using the new mass media, ordinary people assume the socially important functions of professional journalism; therefore, not only is journalism not disappearing, but, on the contrary, it is spontaneously "sprouting up" in the audience itself, as a self-reproducing gene, creating the basis for the future revival of professional journalism. Though the world media are in the process of transformation (Norris, 2017; Langett, 2013; Nygren \& Stigbrand, 2013), we see no reason to worry about the future of journalism: The new media have become the main driving force behind the self-restoration of journalism, in a situation when the traditional media and other social institutions are in crisis.

The futuristic fantasies of M. McLuhan (1965) have turned out to be more realistic than many carefully worked out scientistic forecasts thanks to the evolutionary approach: There is no doubt that the electronic media are changing our civilization by changing every individual. The desire for truth and self-determination is becoming a general trend based on the new media, and is creating a new type of person (Deryabina, 2016; Deryabina, 2017; Pronin \& Pronina 2013). In an information society, the journalist's self-identification is the main instrument of personality evolution, and so lays the groundwork for the next step in the evolution of civilization as a whole.

\section{References}

Amzin, A., Galustian, A., Gatov, V., Kastel's, M., Kul'chitskaia, D., Loseva, N. ... \& van der Haak, B. (2016). Kak novye media izmenili zhurnalistiku. 2012-2016 [How the new media has changed journalism. 2012-2016]. Ekaterinburg: Gumanitarnyy universitet [The Univer- 
sity of Humanities]. Retrieved from http://newmedia2016.digital-books.ru/wp-content/ uploads/2016/06/New-Media-2016.pdf

Chudova, N. V., Evlampieva, M. A., \& Rakhimova, N. A. (2002). Psikhologicheskiy portret potrebitelya internet-informatsii. [A psychological portrait of the consumer of online information]. In E. E. Pronina (Ed.), Problemy mediapsikhologii [Issues of media psychology] (pp. 117-131). Moscow: RIP-Holding. Retrieved from http://evartist.narod.ru/text7/47.htm

Deryabina, A. S. (2016). Pravdivost', ob"ektivnost' i gumanizm v vospriyatii zhurnalistov razlichnykh SMI [Truthfulness, objectivity and humanism in the perception of journalists from different media]. Mediaskop, 3. Retrieved from http://www.mediascope.ru/?q=node/2133

Deryabina, A. S. (2017). Stremlenie k samodeterminatsii v strukture professional'noy identichnosti zhurnalista [Desire for self-determination in the professional identity of the journalist]. Mediaskop, 4. Retrieved from http://www.mediascope.ru/2391

Deuze, M. (2008). The professional identity of journalists in the context of convergence culture. Observatorio (OBS) Journal, 7, 103-117. Retrieved from http://citeseerx.ist.psu.edu/view$\mathrm{doc} /$ download?doi=10.1.1.476.9278\&rep=rep1\&type $=$ pdf

Frolova, T. I. (2013). Grazhdanskie prilozheniya v strukture mediakommunikatsiy [Civil applications in the structure of media communications]. In E. L. Vartanova, A. A. Gladkova, \& M. I. Makeenko (Eds.), Natsional'nye mediasistemy mezhdu natsional'nym i globalnym: modeli i trendy 2010-kh [National media systems between national and global: Models and trends of the 2010s] (pp. 282-289). Moscow: Faculty of Journalism, Moscow State University Publ.

Frolova, T.I. (2014). Praktika grazhdanskikh kommunikatsiy v tsifrovoy srede: opyt sistematizatsii. [Civil communications in a digital environment: The experience of systematization]. Vestnik Moskovskogo Universiteta. Seriya 10, Zhurnalistika [Moscow University Journalism Bulletin], 2, 29-47.

Kokhanov, E.F., Kravtsov, V.V., \& Shkondin, M.V. (2015). Zhanrovaya struktura novykh media $\mathrm{v}$ usloviyakh transformatsii mediasistemy. [Genre structure of the new media under conditions of transformation of the media system]. Vestnik Volzhskogo universiteta im. V.N. Tatishcheva [Bulletin of Tatishchev Volga University], 2, 36-39.

Kuznetsova, Yu. M. (2011). Kartina mira i sovremennye tekhnologii: "legkost' bytiia" v Internet [Picture of the world and modern technology: "lightness of being" on the Internet]. Chelovek kak sub"ekt i ob"ekt mediapsikhologii. [Man as the subject and the object of media psychology]. Moscow: Izdatel'stvo MGU, 437-467.

Kuznetsova, Yu. M., \& Chudova, N.V. (2008). Psikhologiya zhiteley Interneta [The psychology of Internet inhabitants]. Moscow: Izdatel'stvo LKI.

Langett, J. (2013). Blogger engagement ethics: Dialogic civility in a digital era. Journal of Mass Media Ethics, 28 (2), 79-90. https://doi.org/10.1080/08900523.2013.751817

Lazutina, G.V. (2013). Professionalnaya etika zhurnalista [Professional ethics of the journalist]. Moscow: Aspekt Press.

Loseva, N. (2016). Auditoriya novykh media [The audience of the new media] In S. Balmaeva \& M. Lukina (Eds.), Kak novye media izmenili zhurnalistiku. 2012-2016 [How new media has changed journalism. 2012-2016]. Ekaterinburg: Gumanitarnyy universitet [University of the Humanities]. Retrieved from http://newmedia2016.digital-books.ru/wp-content/ uploads/2016/06/New-Media-2016.pdf

McLuhan, M. (1965). Understanding media: The extensions of man. New York: McGraw-Hill.

Mediamakers: Trend report 2016-2020. Third conference of RBS. Retrieved from http://mediamakers.ru/upload/specials/mediamakers/MediaMakersTrendsReport.pdf

Mitchell, A. (1984). Nine American lifestyles: Who we are and where we're going. Warner Books. 
Nasledov, A.D. (2011). SPSS 19 professional'nyy statisticheskiy analiz dannykh [SPSS 19 professional statistical analysis of data]. Saint Petersburg.

Norris, W. (2017). Digital humanitarians: Citizen journalists on the virtual front line of natural and human-caused disasters. Journalism Practice, 11, 213-228. https://doi.org/10.1080/175 12786.2016.1228471

Nygren, G., \& Stigbrand, K. (2013). Professional identity in changing media landscapes. Stockholm: Elanders. Retrieved from http://sh.divaportal.org/smash/get/diva2:665879/FULLTEXT01.pdf

Prognozy mediaekspertov [Predictions of media experts] (2017). Mediatrendy [MediaTrends], 1. Retrieved from https://drive.google.com/file/d/0B_lP1f66chKIeW50bGo5S3h6N1E/view

Pronin, E.I. (2002). Psikhologicheskie problemy sovremennoy zhurnalistiki [Psychological issues in modern journalism]. In E.E. Pronina (Ed.). Problemy mediapsikhologii [Issues in media psychology] (pp. 5-18). Moscow: Rip-holding. Retrieved from http://evartist.narod. $\mathrm{ru} / \mathrm{text} 7 / 39 . \mathrm{htm}$

Pronin, E.I., \& Pronina, E.E. (1995). Grazhdane, poslushayte sebya [People, listen to yourselves]. Politicheskaya sreda [Political Wednesday], 2.

Pronin, E.I., \& Pronina, E.E. (2013). Mediapsikhologiya: Noveyshie informatsionnye tekhnologii i fenomen cheloveka [Media psychology: The latest information technologies and the phenomenon of man]. Obshchestvennye nauki i sovremennost' [Social Sciences and Modernity], 2, 151-161.

Pronina, E.E. (2014). Media psychology: Modern man and nonlocality of psyche. Psychology in Russia. State of the Art, 4 (7), 75-87. https://doi.org/10.11621/pir.2014.0407

Vartanova, E.L. (2014). Postsovetskie transformatsii rossiyskikh SMI $i$ zhurnalistiki [Post-Soviet transformation of Russian media and journalism]. Moscow: MediaMir.

Vartanova, E.L. (2015). About three vectors of future journalism. Medi@l'manakh [Media almanac], 3 (68), 8-11.

Verbitskaya, Yu.A. (2006). Massovaya kommunikatsiya kak tvorcheskaya problema: tekst i lichnost' [Mass communication as a creative problem: Text and personality] (Doctoral dissertation) Moscow State University, Moscow.

Vyrkovskiy, A.V., Vartanov, S.A., Galkina, M.Yu., Kolesnichenko, A.V., \& Obraztsova, A.Yu. (2016). Struktura rabochego protsessa rossiyskogo zhurnalista [The working process of a Russian journalist]. Mediaskop, 2. Retrieved from http://www.mediascope.ru/?q=node/2105

Young, S., \& Carson, A. (2016). What is a journalist? The view from employers as revealed by their job vacancy advertisements. Journalism Studies, 0 (0), 1-21. 